Research Paper

\title{
Catalytically defective receptor protein tyrosine kinase PTK7 enhances invasive phenotype by inducing MMP-9 through activation of AP-1 and NF-KB in esophageal squamous cell carcinoma cells
}

\author{
Won-Sik Shin ${ }^{1}$, Yuri Hong ${ }^{1}$, Hae Won Lee ${ }^{2}$, Seung-Taek Lee ${ }^{1}$ \\ ${ }^{1}$ Department of Biochemistry, College of Life Science and Biotechnology, Yonsei University, Seoul, Republic of Korea \\ ${ }^{2}$ Department of Thoracic Surgery, Korea Cancer Center Hospital, Korea Institute of Radiological and Medical Sciences, Seoul, \\ Republic of Korea
}

Correspondence to: Seung-Taek Lee, email: stlee@yonsei.ac.kr

Keywords: $P T K 7, M M P-9, N F-K B, A P-1$, esophageal squamous cell carcinoma (ESCC)

Received: June 04, 2016

Accepted: September 21, 2016

Published: September 28, 2016

\section{ABSTRACT}

Protein tyrosine kinase 7 (PTK7), a member of the catalytically defective receptor protein tyrosine kinase family, is upregulated in various cancers including esophageal squamous cell carcinoma (ESCC). Here, we have explored the molecular mechanism of PTK7-dependent invasiveness in ESCC cells. PTK7 knockdown reduced gelatin degradation and MMP-9 secretion in cultures of ESCC TE-10 cells, and showed reduced levels of MMP9 mRNA using real-time RT-PCR and luciferase reporter assays. PTK7 knockdown decreased not only phosphorylation of NF-KB, IKB, ERK, and JNK, but also nuclear localization of NF-KB and AP-1 consisting of c-Fos and c-Jun. Activation of AP-1 and NF-KB requires PTK7-mediated activation of tyrosine kinases, including Src. In addition, NF-KB activation by PTK7 involves the PI3K/Akt signaling pathway. PTK7-mediated upregulation of MMP9 was also observed in other ESCC cell lines and in three-dimensional cultures of TE-10 cells. Moreover, MMP-9 expression positively correlated with PTK7 expression in ESCC tumor tissue. These findings demonstrate that PTK7 upregulates MMP9 through activation of AP-1 and NF-KB and, thus increases invasive properties of ESCC cells.

\section{INTRODUCTION}

Protein tyrosine kinase 7 (PTK7) consists of an extracellular domain with seven immunoglobulin-like loops, a transmembrane domain, and a tyrosine kinase domain that lacks detectable kinase activity; therefore, PTK7 is a member of the family of catalytically defective receptor protein tyrosine kinases (RPTKs) [1-4]. Homozygosity for a truncated PTK7 gene was perinatally lethal in mice and associated with severe developmental defects, including defective neural tube closure [5]. PTK7 mutant mice phenotypically overlap with known planar cell polarity (PCP) mutant mice and frogs, and PTK7 is genetically linked to Vang12, a core PCP gene. PTK7 also interacts with canonical Wnt pathway proteins, including $\beta$-catenin, and triggers their target genes in Xenopus development, such as formation of Spemann's organizer [6]. Moreover, PTK7 interacts with Wnt5A, non-canonical
Wnt/PCP ligand, and induces JNK activation during morphogenetic movements in Xenopus [7]. These findings suggest that PTK7 regulates PCP, canonical and noncanonical Wnt signaling pathways during development.

PTK7 is upregulated in esophageal squamous cell carcinoma (ESCC) [8], colorectal cancer [9, 10], and other cancers [11-15]. PTK7 enhances proliferation, survival, and migration of various cancer cells $[8,11,13,16]$. PTK7 increases activation of ERKs, JNK, and p38 in ESCC and vascular endothelial cells [8, 17], and decreases expression of BAX and cleavage of caspase- $3,-8$, and -9 in cholangiocarcinoma [15]. In colon cancer and ovarian cancer, PTK7 sensitizes canonical Wnt and non-canonical Wnt/PCP pathways, respectively [6, 18]. However, PTK7 also has a tumor-suppressive role in some cancer types [19-22]. The mechanism(s) underlying the contradictory roles played by PTK7 in different cancer types is unclear. Recently, we demonstrated that PTK7 displays phenotypes 
ranging from oncogenic to tumor-suppressive depending on its concentration relative to those of its binding partners, such as kinase insert domain receptor (KDR) [17]. Our finding of a biphasic function of PTK7 explains in part the discrepancy in the expression-level-dependent oncogenic functions of PTK7.

In a previous report, we described increased PTK7 expression in tumor tissue of ESCC patients and its correlation with poor prognosis [8]. Moreover, PTK7 knockdown inhibited invasiveness and other oncogenic phenotypes of ESCC cells. In an attempt to identify a proteolytic enzyme responsible for the PTK7mediated invasiveness, we performed fluorescent gelatin degradation assay and gelatin zymography. We identified matrix metalloproteinase (MMP)-9 as an enzyme responsible for the invasiveness, analyzed signaling pathways involved in induction of MMP-9, and described the molecular mechanism underlying PTK7-mediated invasiveness in ESCC TE-10 cells. We also demonstrate the correlation of PTK7 expression and MMP-9 induction in multiple ESCC cell lines and patients.

\section{RESULTS}

\section{PTK7 knockdown inhibits gelatin degradation by reducing MMP-9 secretion in ESCC TE-10 cells}

We analyzed whether PTK7 stimulates focal proteolytic degradation of extracellular matrix (ECM) components in ESCC TE-10 cell cultures using a fluorescent gelatin degradation assay. Two lines of PTK7 knockdown cells, PTK7-KD-6433 and PTK7-KD-6434, showed significantly decreased degradation of FITClabeled gelatin compared to control vector-transfected cells (Figure 1). To examine whether the gelatinases MMP-2 and MMP-9 are involved in PTK7-mediated gelatin degradation, extent of gelatin degradation was analyzed in TE-10 cells overexpressing tissue inhibitor of metalloproteases (TIMP)-1 and TIMP-2 (Figure 2A). TIMP-1 expression significantly reduced gelatin degradation to the similar extent as PTK7 knockdown in TE-10 cells. However, TIMP-2 expression inhibited gelatin degradation poorly in TE-10 cells. It is known that TIMP-1 inhibits both MMP-2 and MMP-9 and that TIMP-2 inhibits MMP-2, but not MMP-9 [23]. Thus, this observation suggests that PTK7-induced gelatin degradation is mediated by increased MMP-9 secretion in TE-10 cells.

To further confirm this finding, conditioned medium of control vector-transfected and PTK7-knockdown cells was analyzed by gelatin zymography and western blotting (Figure 2B). MMP-9 secretion was significantly decreased in PTK7 knockdown cells compared to control cells. Expression of exogenous PTK7-FLAG in the PTK7 knockdown cells restored MMP-9 secretion (Figure 2B, left panel). Moreover, gradual decrease of
PTK7 expression using single and double transfection of two knockdown vectors is in parallel with decrease of MMP-9 secretion in TE-10 cells. PTK7 knockout almost completely abolished MMP-9 secretion (Figure 2B, right panel). MMP-2 secretion was not detected in ESCC TE-10 cells, regardless of PTK7 expression status. These results demonstrate that PTK7 is indispensable for MMP-9 expression in TE-10 cells.

\section{PTK7 shedding is not involved in PTK7-induced MMP-9 secretion in TE-10 cells}

We previously reported that a cytosolic domain (CTF2) of PTK7 generated by sequential cleavage by ADAM17 and $\gamma$-secretase translocates into nucleus and enhances oncogenic phenotype of colon cancer cells [24]. However, the extracellular domain of PTK7, which can be produced by its shedding, was not detected in the conditioned medium of TE-10 cells (Supplementary Figure S1A). Incubation with GW280264X (ADAM 17/10 inhibitor) and/or DAPT (gamma-secretase inhibitor) to inhibit generation of PTK7-CTF2, did not change the secreted MMP-9 level in TE-10 cells (Supplementary Figure S1A). Therefore, we assume that PTK7-CTF2 is not produced in TE-10 cells. In addition, ectopic expression of PTK7-CTF2 did not change the secreted MMP-9 level although some of the expressed PTK7-CTF2 was detected in nucleus (Supplementary Figure S1B). Therefore, we conclude that PTK7-CTF2 does not affect induction of MMP-9 expression in TE-10 cells.

\section{PTK7 knockdown decreases transcription of MMP9 mRNA in TE-10 cells}

To examine whether decreased MMP-9 secretion level is the result of decreased MMP 9 mRNA level, control vector-transfected cells and PTK7-knockdown cells were analyzed by reverse transcription (RT)-PCR and reporter assays. In PTK7-KD-6433 and PTK7KD-6434 cells, MMP9 mRNA levels were reduced to $20 \%$ and $15 \%$ and PTK7 mRNA levels were reduced to $26 \%$ and $12 \%$, respectively, compared to control cells (Figure 3B). Consistent with the absence of secreted MMP-2 (Figure 2B), MMP2 mRNA was not detected in TE-10 cells (Figure 3A). Luciferase activity driven by the MMP9 promoter was decreased to $45 \%$ and $39 \%$ of control values in PTK7-KD-6433 and 6434 cells, respectively (Figure 3C). These findings show that PTK7 upregulates $M M P 9$ at the transcriptional level.

\section{PTK7 knockdown inhibits phosphorylation of $\mathbf{\kappa} \mathrm{B}, \mathrm{NF}-\kappa \mathrm{B}$, and mitogen-activated protein kinases (MAPKs) in TE-10 cells}

MMP9 gene expression is increased primarily by transcription factors AP-1 and NF-кB [25]. Therefore, we 
analyzed phosphorylation of $\mathrm{I} \kappa \mathrm{B}$ and $\mathrm{NF}-\kappa \mathrm{B}$, as indicators of NF- $\kappa \mathrm{B}$ activation status, and of ERK and JNK, as indicators of AP-1 activation status, in PTK7 knockdown cells (Figure 4A). Phosphorylation of I $\kappa$ B, NF- $\kappa$ B, ERK, and JNK was reduced in the PTK 7 knockdown cells, and nuclear levels of AP-1 consisting of c-Fos and c-Jun, and $\mathrm{NF}-\kappa \mathrm{B}$ were decreased in the PTK7 knockdown cells compared to control cells (Figure 4B). These observations show that PTK7 upregulates MMP-9 by activating the $\mathrm{NF}-\kappa \mathrm{B}$ and AP-1 signaling pathways.

\section{RPTKs and Src are involved in PTK7-mediated activation of NF- $\mathrm{NB}$ and $\mathrm{AP}-1$ in TE-10 cells}

To elucidate the signal transduction pathway involved in PTK7-mediated NF- $\kappa$ B activation, phosphorylation of various signaling proteins in the presence of signaling inhibitors was analyzed in control and PTK7 knockdown cells. Total tyrosine phosphorylation was decreased in PTK7-KD-6433 and -6434 cells compared to control vector cells (Figure 5A). Because a dramatic decrease in tyrosine phosphorylation was detected in proteins of approximately $60 \mathrm{kDa}$ and 125-130 kDa, phosphorylation levels of p60 ${ }^{\mathrm{Src}}, \mathrm{p} 125^{\mathrm{FAK}}$, and $\mathrm{p} 130^{\mathrm{CAS}}$ were analyzed. Phosphorylation of all three proteins was decreased in PTK7 knockdown cells (Figure 5B). Incubation of control vector-transfected TE10 cells with a pan-PTK inhibitor (genistein), a multitarget RPTK inhibitor (TKI-258), and Src family kinase inhibitors (PP1 and PP2) decreased not only tyrosine phosphorylation of total cellular proteins and $\mathrm{Src}$, but also phosphorylation of $\mathrm{I} \kappa \mathrm{B}, \mathrm{NF}-\kappa \mathrm{B}, \mathrm{ERK}$, and $\mathrm{JNK}$, to the same extent as seen in PTK7 knockdown cells treated with vehicle control dimethyl sulfoxide (DMSO) (Figure 5C). Moreover, expression of dominant-negative mouse Src (mSrc-DN) decreased phosphorylation of Src, I $\kappa \mathrm{B}, \mathrm{NF}-\kappa \mathrm{B}$, ERK, and JNK, as much as the levels in PP1-treated or PTK7-knockdwon TE-10 cells (Figure 5D). These results suggest that PTK7 activates AP-1 and NF- $\mathrm{BB}$ signaling pathways through RPTKs and Src in TE-10 cells.

\section{PI3K and Akt are required for PTK7-mediated $\mathrm{NF}-\kappa \mathrm{B}$ activation in TE-10 cells}

The PI3K/Akt pathway activates NF- $\mathrm{B}$ through phosphorylation of the I $\mathrm{B}$ kinase (IKK) complex in colorectal cancer cell [26]. In TE-10 cells, PTK7 knockdown decreased phosphorylation of Akt, I $\mathrm{B}$, and NF- $\kappa \mathrm{B}$ (Figure 6A). As expected, PI3K inhibitor LY294002 decreased phosphorylation of I $\kappa$ B and NF- $\kappa$ B in control vector-transfected cells, whereas MEK inhibitor PD98059 and JNK inhibitor SP600125 did not inhibit phosphorylation of either protein. In PTK7 knockdown cells, phosphorylation of Akt, IKK $\alpha$ (Thr23), IKK $\alpha / \beta$ (Ser176/180), and IкB was significantly decreased, to the same extent as observed in LY294002-treated and dominant-negative Akt-overexpressing TE-10 cells (Figure 6B). These findings indicate that PTK7 enhances $\mathrm{NF}-\kappa \mathrm{B}$ phosphorylation through the PI3K-Akt signaling pathway in ESCC TE-10 cells.
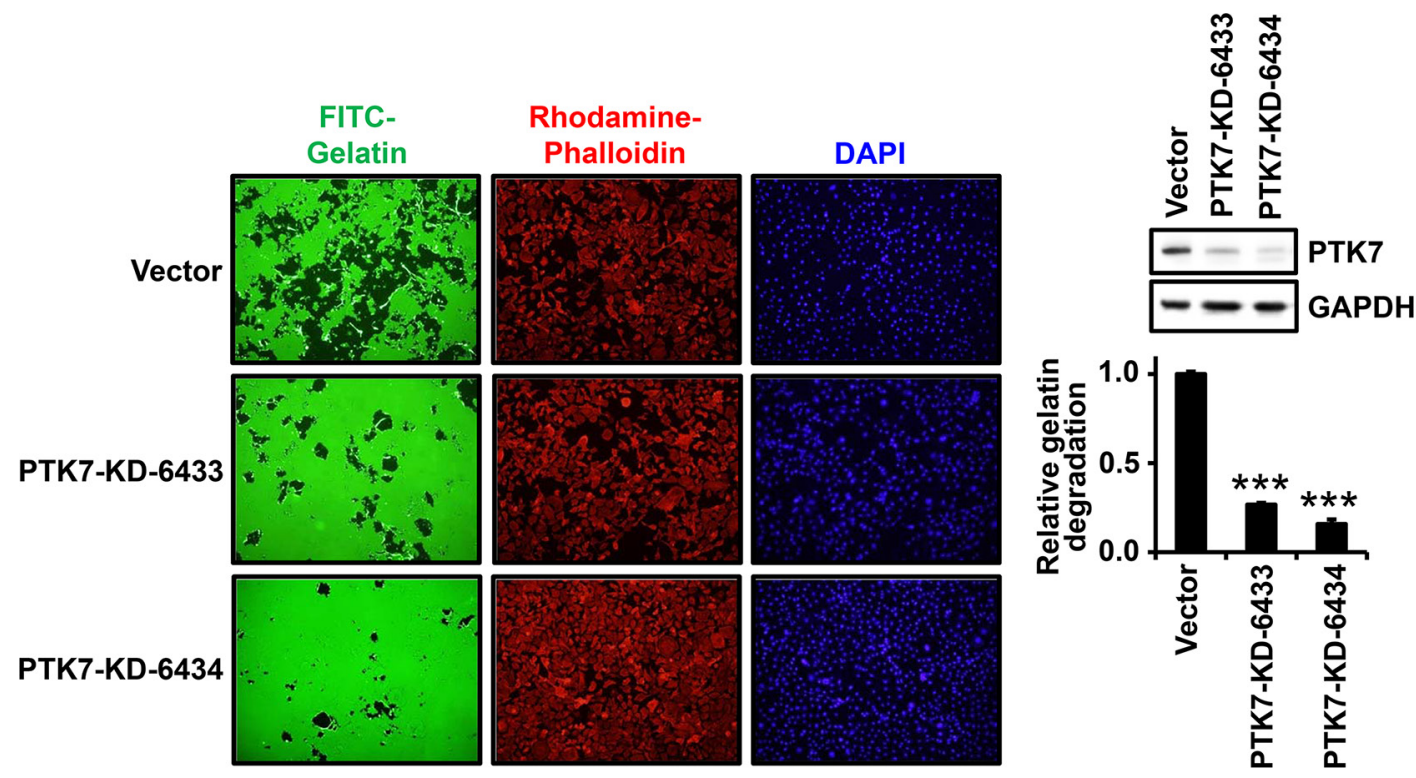

Figure 1: Effect of PTK7 knockdown on gelatin degradation by TE-10 cells. Control vector-transfected and PTK7 knockdown (PTK7-KD-6433 and -6334) TE-10 cells were plated at $4 \times 10^{4}$ cells/well of 24-well plate on FITC-gelatin-coated cover glasses and incubated for $48 \mathrm{~h}$ at $37^{\circ} \mathrm{C}$. The cells were stained with rhodamine-phalloidin and DAPI, and analyzed by fluorescence microscopy $(\times 100)$. Western blot on right shows PTK7 levels in control and PTK7 knockdown cells. GAPDH served as loading control. Relative gelatin degradation was shown as FITC-gelatin degraded area normalized to DAPI intensity of the sample referred to that of the control vectortransfected cells. $* * * P<0.001$ vs. control vector-transfected cells. 


\section{Blockade of PTK7-induced signaling pathways attenuates MMP9 upregulation in $2 \mathrm{D}$ and $3 \mathrm{D}$ cultures of TE-10 cells}

To confirm that PTK7-induced ERK, JNK, PI3K/ Akt, and NF- $\mathrm{kB}$ signaling pathways are responsible for PTK7-mediated MMP9 upregulation, MMP-9 expression and gelatin degradation were analyzed in $2 \mathrm{D}$ and $3 \mathrm{D}$ cultures of TE-10 cells in the presence of inhibitors of MEK, JNK, PI3K, and NF-KB. In 2D culture, treatment of cells with all tested inhibitors, as well as PTK7 knockdown, significantly decreased the level of secreted MMP-9 (Figure 7A). In 3D culture, intensity of fluorescence generated by degradation of fluorogenic DQ-gelatin was reduced by treatment with MEK, JNK, PI3K, and NF- $\mathrm{KB}$ inhibitors to $31 \%, 35 \%, 21 \%$, and $10 \%$, respectively, of control values (Figure 7B and 7C). In PTK7-KD-6434 cells, fluorescence intensity was reduced to $17 \%$ of control. These results demonstrate that PTK7-mediated transactivation of the MMP9 gene occurs by AP-1 activation, which is associated with activation of ERK and JNK, and by NF- $\mathrm{KB}$ activation, which requires activation of PI3K.

A
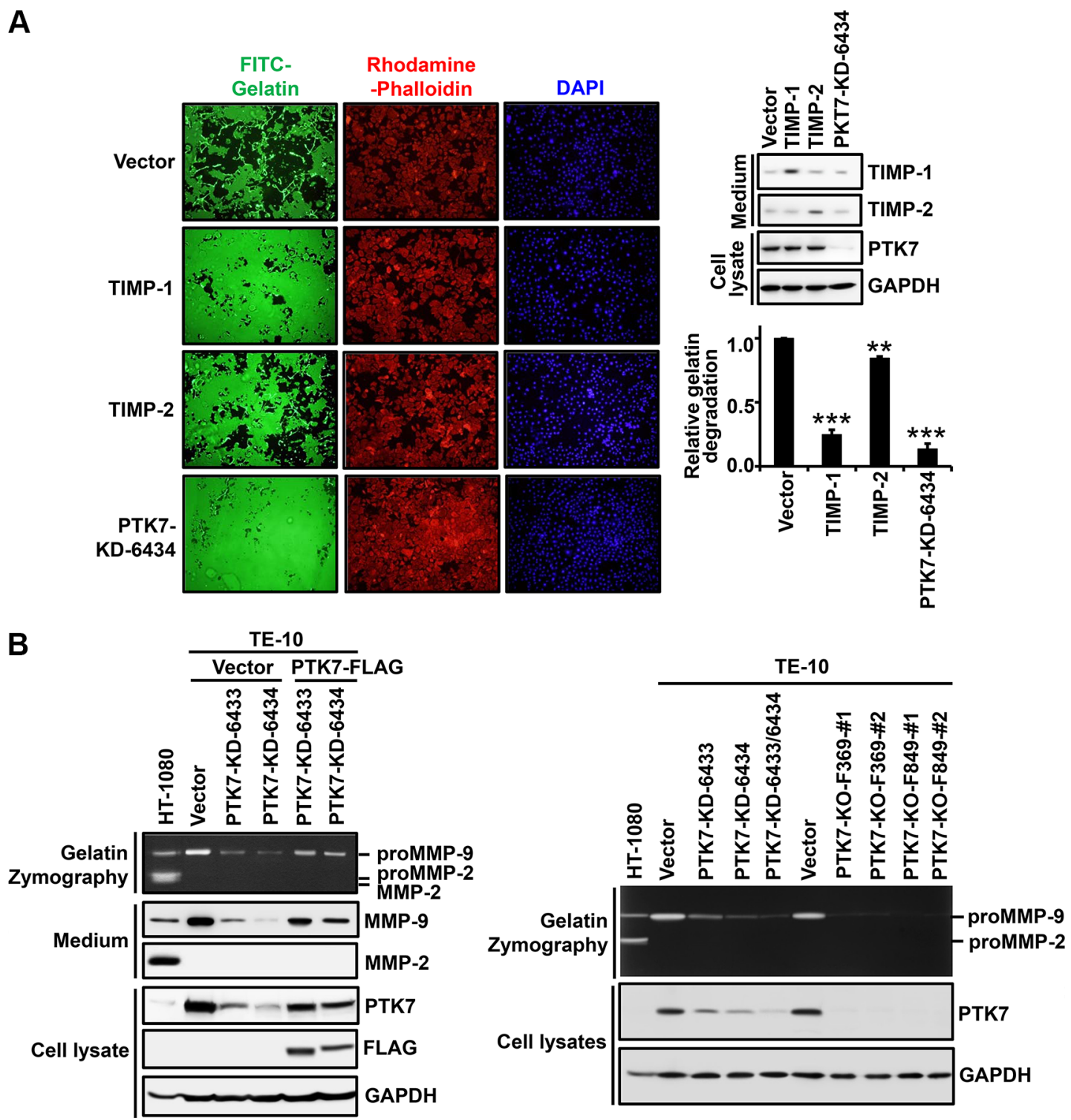

Figure 2: Identification of a gelatinase induced by PTK7 in TE-10 cells. (A) TE-10 cells overexpressing TIMP-1 or TIMP-2 were grown on FITC-gelatin-coated coverslips, stained with rhodamine-phalloidin and DAPI, and analyzed by fluorescence microscopy $(\times 100)$. Western blot on right shows TIMP-1 and TIMP-2 levels in conditioned medium and PTK7 level in cell lysates. Relative gelatin degradation was shown as FITC-gelatin degraded area normalized to DAPI intensity of the sample referred to that of the control vectortransfected cells. ${ }^{* *} P<0.01,{ }^{* * *} P<0.001$ vs. control vector-transfected cells. (B) Levels of secreted MMP-2 and MMP-9 and PTK7 were analyzed by gelatin zymography and western blotting in conditioned medium and cell lysates. PTK7 knockdown (PTK7-KD-6433 and 6434) TE-10 cells transfected with empty vector (Vector) or PTK7 overexpression vector (PTK7-FLAG) (left panel) and PTK7 knockdown (PTK7-KD-6433, 6434, and 6433/6434) or PTK7 knockout (2 cell lines of PTK7-KO-F369 and F849) TE-10 cells (right panel) were used. HT-1080 cell conditioned medium was used to show positions of MMP-9 and MMP-2. 


\section{PTK7 expression is correlated with MMP-9 expression in other cells and tumor tissue of ESCC}

We analyzed levels of PTK7 and secreted MMP-9 in non-neoplastic esophageal epithelial cell lines and ESCC cell lines (Figure 8A). Both PTK7 and MMP-9 were expressed at a low level in the non-neoplastic esophageal epithelial cell lines NE1 and NE2. In the ESCC cell lines TE-5, TE-6, TE-9, TE-10, TE-11, and TE-14, levels of MMP-9 secretion varied. Interestingly, cells showing elevated PTK7 expression also showed elevated MMP-9 secretion (Figure 8A). PTK7 knockdown in TE-6, TE-9, and TE-10 cells reduced levels of secreted MMP-9 (Figure 8B). In PTK7 knockdown TE-6, TE-9, and TE-10 cells, PTK 7 mRNA levels were decreased to $34 \%, 27 \%$, and $12 \%$ respectively, of control values, and in these cells MMP9 mRNA levels were decreased to $20 \%, 30 \%$, and
$14 \%$, respectively, of control (Figure $8 \mathrm{C}$ and $8 \mathrm{D}$ ). Thus, we are confident that PTK 7 enhances $M M P 9$ expression at the transcriptional level in other ESCC cells as well as in TE- 10 cells.

To investigate whether PTK7 expression was correlated with that of MMP-9 in vivo, tumor tissue from 155 ESCC patients was immunohistochemically stained with anti-PTK7 and anti-MMP-9 antibodies and staining intensity was analyzed. Representative images of PTK7 and MMP-9 staining in each tissue block are shown in Figure 9A. PTK7 and MMP-9 are enriched at pericellular region of cancer cells but not around normal cells. Spearman's rank correlation analysis showed that PTK7 expression was significantly correlated with MMP-9 expression (Figure 9B; Spearman's rank: $r=0.4$ and $P=4.5 \times 10^{-7}$ ). These findings support the idea that PTK7 expression is responsible for the induction of MMP-9 in ESCC tumor tissue.
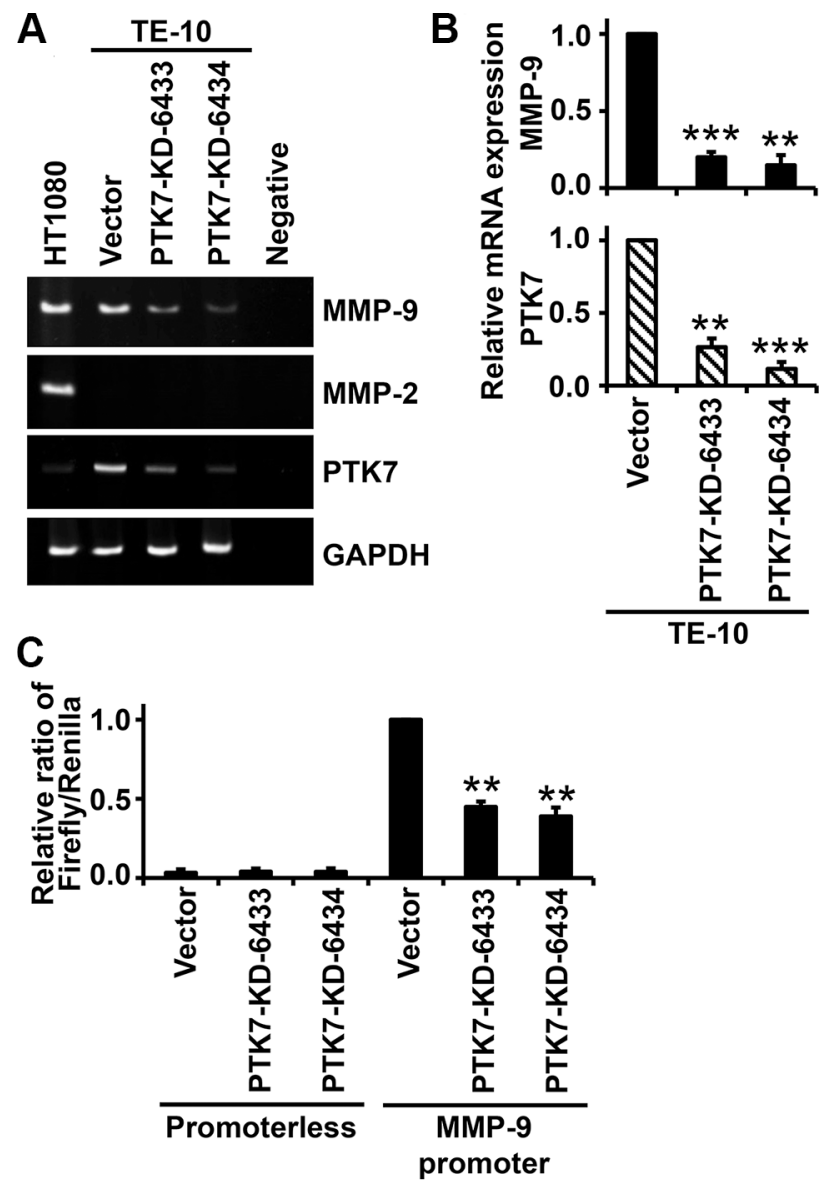

Figure 3: Effect of PTK7 knockdown on MMP9 transcription in TE-10 cells. (A and B) $M M P 9$ mRNA levels in control vectortransfected and PTK7 knockdown (PTK7-KD-6433 and -6434) TE-10 cells were analyzed by conventional RT-PCR (A) and real-time RT-PCR (B). (A) PCR products were separated by PAGE in $\%$ gels and visualized by ethidium bromide staining. (B) Relative expression levels of MMP9 and PTK7 mRNA determined by real-time PCR. ${ }^{* *} P<0.01,{ }^{* * *} P<0.001 v s$. those in control vector-transfected cells. (C) Control vector-transfected and PTK7 knockdown TE-10 cells were cotransfected with pRL-TK and pGL3-M9P-wt (MMP9 promoter) or pGL3-Basic (promoterless). Luciferase activity is shown as ratio of firefly/Renilla luciferase activity. ${ }^{* *} P<0.01 v s$. luciferase activity in control vector-transfected TE-10 cells transfected with pGL3-M9P-wt. 


\section{DISCUSSION}

In this study, we found that PTK7 knockdown reduced focal degradation of underlying gelatin in TE-10 cell cultures. MMP-9 is the major enzyme responsible for PTK7-dependent gelatin degradation, and PTK7 induces $M M P 9$ at the transcriptional level. Transactivation of the $M M P 9$ gene is stimulated primarily by transcription factors AP-1 and NF- $\mathrm{KB}$ [27]. We found that PTK7 increased nuclear levels of c-Fos and c-Jun through activation of ERK and JNK and increased the level of activated NF- $\kappa \mathrm{B}$ by phosphorylation and degradation of I $\mathrm{B}$ and phosphorylation of RelA/p65.

It is interesting to understand how PTK7 activates MAPKs and IKK to activate AP-1 and NF- $\mathrm{KB}$. Knockdown of PTK7 decreased tyrosine phosphorylation of cellular proteins in TE-10 cells. Although PTK7 is a catalytically defective RPTK, it might recruit protein tyrosine kinases and enhances downstream signaling pathways. It was well known that HER3, a catalytically defective RPTK, can heterodimerize with other EGFR family members upon ligand binding such as neuregulin and activates downstream signaling proteins such as Akt and Erk [28]. We have previously demonstrated that PTK7 binds to and activates KDR, one of VEGF receptor [17]. However, KDR expression was not detectable in TE-10 cells. Nevertheless, pan-PTK inhibitor genistein and multitarget RPTK inhibitor TKI-258 inhibited phosphorylation

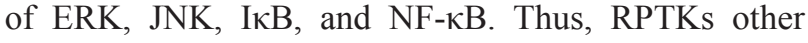
than KDR might work with PTK7 for downstream activation. We also found that PTK7 knockdown decreases phosphorylation of Src and Src substrate CAS [29]. Indeed, treatment of Src family kinase inhibitors PP1 and PP2 and expression of dominant-negative Src decreased activation of ERK, JNK, I $\mathrm{KB}$, and NF- $\mathrm{kB}$ to the same extent as PTK7 knockdown. It was reported that PTK7 coprecipitates with Src and enhances Src activity [30]. In addition, Src is known to activate NF- $\mathrm{KB}$, as well as ERKs and JNK $[31,32]$. These reports support the idea that Src may be a PTK involved in PTK7-mediated activation of AP-1 and NF-KB.

Interestingly, we found that PTK7-mediated phosphorylation of I $\mathrm{KB}$ and NF- $\mathrm{kB}$ was inhibited by a PI3K inhibitor, LY294002. IKK $\alpha$ is phosphorylated at $\mathrm{Thr} 23$ by Akt, and IKK $\alpha / \beta$ is phosphorylated at Ser176/180 by NIK and TAK1 or autophosphorylated by the IKK complex [33]. In our study, phosphorylation of IKK $\alpha$ at Thr23 and of IKK $\alpha / \beta$ at Ser176/180 was decreased by LY294002 treatment and overexpression of dominant-negative Akt. Thus, the PTK7-activated PI3K/ Akt pathway appears to activate IKK in ESCC TE-10 cells. The signaling pathways involved in PTK7-induced MMP-9 expression are summarized in Figure 10.

We have shown that the pro-invasive effect of PTK7 occurs through enhanced MMP-9 secretion in 2D culture conditions. In vivo, cells are surrounded by ECM and grow
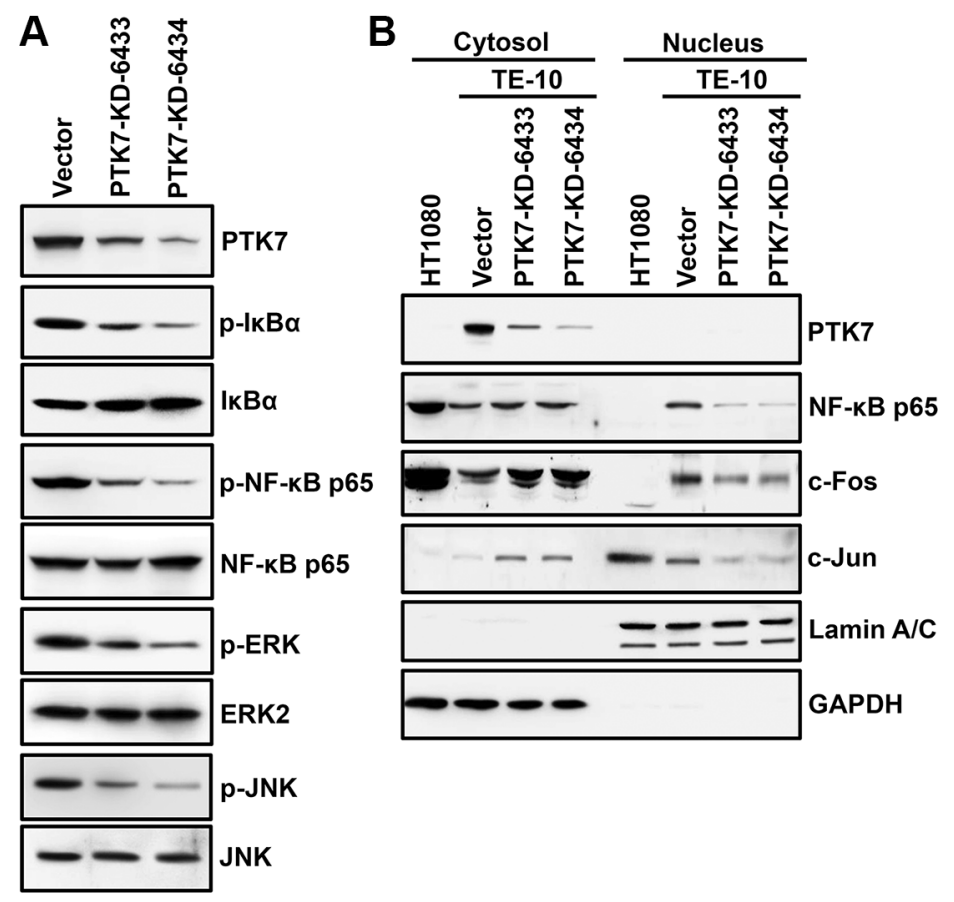

Figure 4: Effect of PTK7 knockdown on NF-кB and AP-1 activation in TE-10 cells. Activation of NF- $\mathrm{B}$ and AP-1 was analyzed in control vector-transfected and PTK7 knockdown (PTK7-KD-6433 and 6434) TE-10 cells. (A) Phosphorylation of NF-kB and $\mathrm{I} \kappa \mathrm{B}$ as indicators of NF- $\mathrm{KB}$ activation, and phosphorylation of ERK and JNK as indicators of activation of AP-1 were analyzed by western blotting. (B) Nuclear and cytosolic fractions were prepared from control and PTK7 knockdown cells. Levels of AP-1 complex components, c-Fos and c-Jun, and NF- $\mathrm{kB}$ were analyzed by western blotting. GAPDH and lamin A/C served as cytosolic and nuclear markers, respectively. 
or migrate through ECM proteolysis [34]. Use of a 3D culture system that incorporates Matrigel and DQ-gelatin to mimic in vivo conditions, we demonstrated that PTK7 knockdown, as well as inhibition of MEK, JNK, PI3K, and $\mathrm{NF}-\kappa \mathrm{B}$ activation, significantly inhibited degradation of ECM components.

Gelatinase activity is frequently increased in ESCC and is correlated with tumor invasion and metastasis [35]. We previously demonstrated that PTK7 expression is related to poor prognosis of ESCC patients [8]. Here, we showed that PTK7 expression is required for transcription and secretion of MMP-9 in multiple ESCC cell lines that express PTK7. Although $M M P 9$ induction is controlled by various stimuli and signaling pathways, we have shown that PTK7 expression is positively correlated with MMP-9 expression in samples of ESCC tumor tissue from 155 patients.

We showed that PTK7 enhances invasiveness through MMP-9 induction by AP-1 and NF-kB activation. Chemoresistant cancer cells often show NF- $\kappa$ B activation, and NF- $\mathrm{B}$ knockdown strengthens the effect of chemotherapeutic agent 5-FU on cell death in cancer cells [36-38]. Consistently, we have shown that PTK7 knockdown sensitizes cells to 5-FU-induced death [8]. These data suggest the possibility that inhibition of PTK7 function reduces $\mathrm{NF}-\kappa \mathrm{B}$ activation and enhances the effect
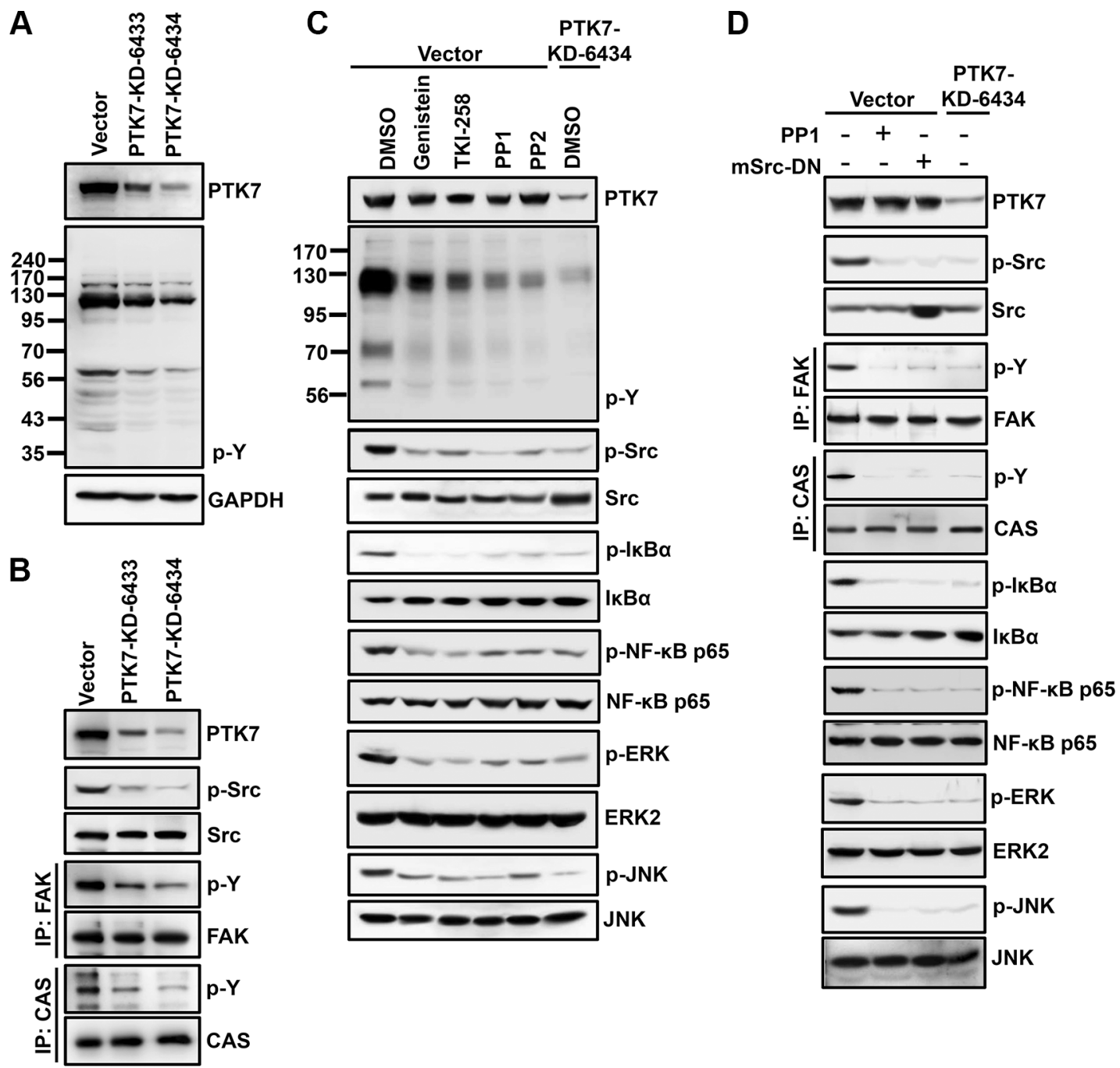

Figure 5: Involvement of PTK in PTK7-mediated activation of NF-KB and AP-1 in TE-10 cells. (A and B) Tyrosine phosphorylation of cellular proteins (A) and $\mathrm{p} 60^{\mathrm{Src}}, \mathrm{p} 125^{\mathrm{FAK}}$, and $\mathrm{p} 130^{\mathrm{CAS}}(\mathrm{B})$ was analyzed by western blotting in control vector-transfected and PTK7 knockdown (PTK7-KD-6433 and 6434) TE-10 cells. Tyrosine phosphorylation of cellular proteins and p60 $0^{\text {Src }}$ was detected by anti-phosphotyrosine (4G10) and anti-phospho-Src family (Tyr416) antibodies, respectively. Tyrosine phosphorylation of p125 ${ }^{\mathrm{FAK}}$ and p130 ${ }^{\mathrm{CAS}}$ was monitored by immunoprecipitation with anti-FAK and anti-CAS antibodies, respectively, and western blotting with antiphosphotyrosine (4G10) antibody. (C) Subconfluent control vector-transfected and PTK7 knockdown (PTK7-KD-6434) TE-10 cells were incubated with genistein $(100 \mu \mathrm{M}$, pan-PTK inhibitor), TKI-258 (200 nM, multi-targeted RTK inhibitor), PP1 or PP2 (10 $\mu$ M, Src family kinase inhibitors), or DMSO (vehicle) for $30 \mathrm{~min}$. (D) Control vector-transfected cells were transfected with dominant-negative mouse Src expression construct (mSrc-DN). Levels of total and phosphorylated forms of the indicated signaling molecules were analyzed by western blotting. 
of 5-FU in chemoresistant cancer cells. Taken together, the data show that PTK7 plays a role in tumorigenesis, invasiveness, and chemoresistance. Thus, attenuation of PTK7 function would be a valuable therapeutic means to control ESCC and other cancers that express PTK7.

\section{MATERIALS AND METHODS}

\section{Reagents and antibodies}

Quenched fluorogenic DQ Gelatin and rhodamineconjugated phalloidin were purchased from Thermo Fisher Scientific (Waltham, MA, USA). Fluorescein isothiocyanate (FITC)-conjugated gelatin, anti-FLAG antibody, and 4',6-diamidino-2-phenylindole (DAPI) were purchased from Sigma-Aldrich (St. Louis, MO, USA). Genistein, PP1, PP2, and LY294002 were purchased from AG Scientific (San Diego, CA, USA). TKI-258 was purchased from ApexBio (Houston, TX, USA). PD98059 and SP600125 were purchased from Tocris Bioscience (Bristol, UK). QNZ and antibodies against phospho-
ERK, ERK2, c-Fos, lamin A/C, phospho-IKK $\alpha$ (Thr23), IKK $\alpha$, NF- $\kappa$ B p65, CAS, FAK, Src, and HA tag were purchased from Santa Cruz Biotechnology (Santa Cruz, CA, USA). Antibodies against phospho-JNK, JNK, c-Jun, phospho-Src family (Tyr416), phospho-Akt (Ser473), Akt, phospho-IKK $\alpha / \beta$ (Ser176/180), IKK $\beta$, phospho$\mathrm{I} \kappa \mathrm{B} \alpha$ (Ser32), I $\kappa \mathrm{B} \alpha$, phospho-NF- $\kappa \mathrm{B}$ p65 (Ser536), and MMP-9 were purchased from Cell Signaling Technology (Danvers, MA, USA). Anti-phosphotyrosine antibody (clone 4G10) and anti-MMP-2 antibody were purchased from Millipore (Billerica, MA, USA). Anti-GAPDH antibody was purchased from AbClone (Seoul, Korea). Horseradish peroxidase-conjugated goat anti-mouse IgG, rabbit IgG, and rabbit anti-goat IgG were purchased from KOMA Biotech (Seoul, Korea). Anti-PTK7 antibody was described previously [39].

\section{Cell culture}

Human ESCC TE-5, TE-6, TE-9, TE-10, TE-11, and TE-14 cells were obtained from the RIKEN BioResource
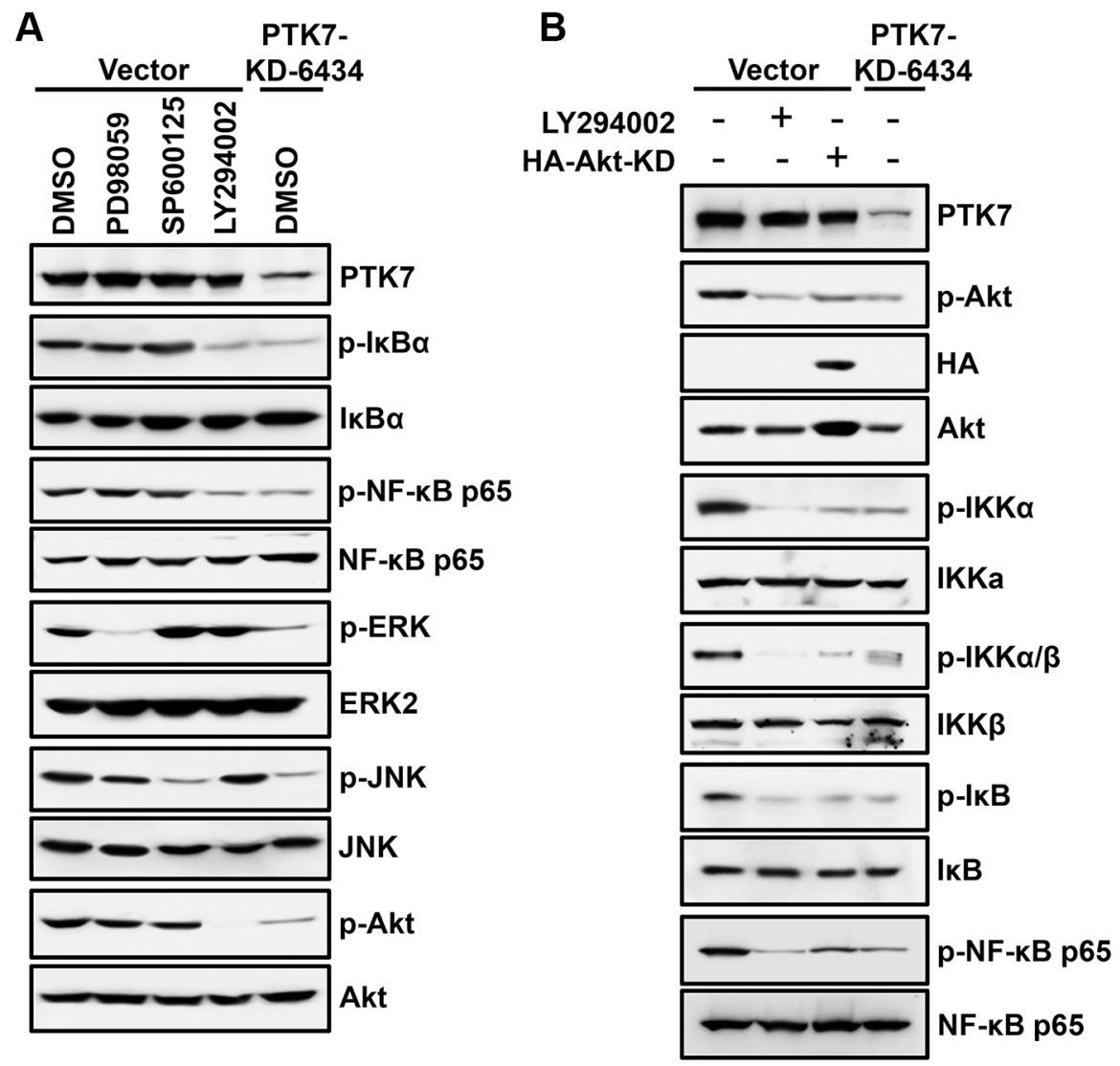

Figure 6: Effect of signaling blockade on the PTK7-mediated NF-кB activation in TE-10 cells. (A) Subconfluent control vector-transfected and PTK7 knockdown (PTK7-KD-6434) TE-10 cells were incubated with PD98059 (30 $\mu$ M, MEK inhibitor), SP600125 (10 $\mu \mathrm{M}$, JNK inhibitor), LY294002 (10 $\mathrm{M}$, PI3K inhibitor), or DMSO (vehicle) for $30 \mathrm{~min}$. Levels of total and phosphorylated forms of the indicated signaling molecules were analyzed by western blotting. (B) Control vector-transfected cells were transfected with dominantnegative Akt expression construct (HA-Akt-KD) or incubated in the presence or absence of LY294002 (10 $\mu \mathrm{M})$ for $30 \mathrm{~min}$. Levels of total and phosphorylated Akt, IKK $\alpha$ (Thr23), IKK $\alpha / \beta$ (Ser176/180), and IKB in the cells were compared with the ones in PTK7 knockdown (PTK7-KD-6434) cells by western blotting. 
Center (Tsukuba, Japan) and human fibrosarcoma HT1080 cells was obtained from Korean Cell Line Bank (Seoul, Korea). These cells were maintained in Dulbecco's modified Eagle medium (DMEM; Gibco/Thermo Fisher Scientific) supplemented with $10 \%$ fetal bovine serum (FBS). Non-neoplastic esophageal epithelial cell lines NE1 [40] and NE2 [41] were provided by Professor G.S.W. Tsao (University of Hong Kong, Hong Kong SAR, China). These cells were maintained in a 1:1 mixture of Epilife medium (Gibco/Thermo Fisher Scientific) and Defined Keratinocyte-SFM (Gibco/Thermo Fisher Scientific) containing $100 \mathrm{U} / \mathrm{ml}$ penicillin and $100 \mu \mathrm{g} / \mathrm{ml}$ streptomycin at $37^{\circ} \mathrm{C}$ in a humidified atmosphere of $5 \% \mathrm{CO}_{2}$ and $95 \%$ air.

\section{Expression vectors, knockdown vectors, and knockout vectors}

Expression vectors pcDNA3.1-TIMP-1 [42] and pcDNA3.1-TIMP-2 [43] encoding human TIMP1 and TIMP-2, respectively, and pcDNA3-hPTK7FLAG [17] encoding human PTK7 with a C-terminal Flag tag were described previously. Expression vector encoding K297R/Y529F dominant-negative mouse Src (pLNCX-mSrc [K297R/Y529F]) was generated by sitedirected mutagenesis using pLNCX-mSrc, which was a generous gift from Professor E.-S. Oh (Ewha Womans University, Korea), as a template and primer pairs listed
A
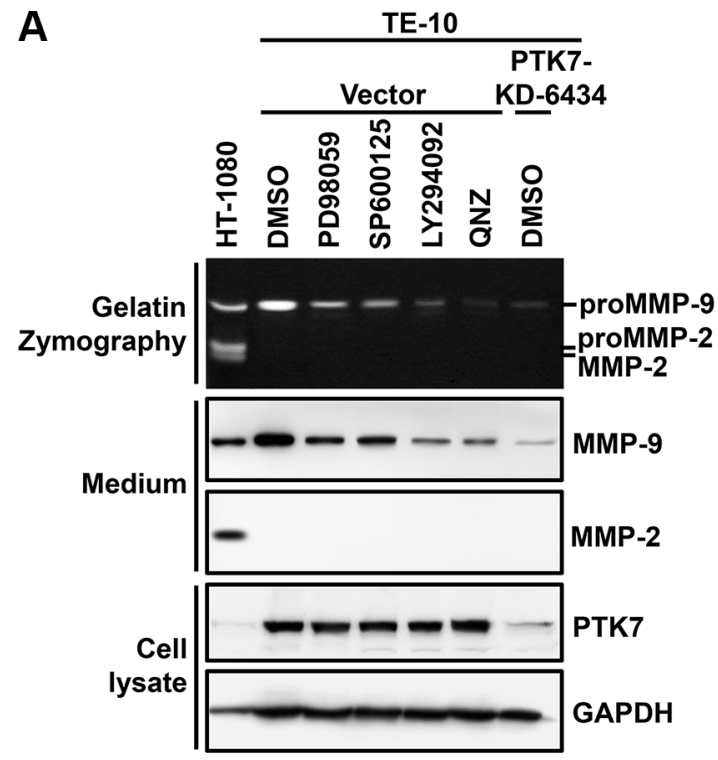

C

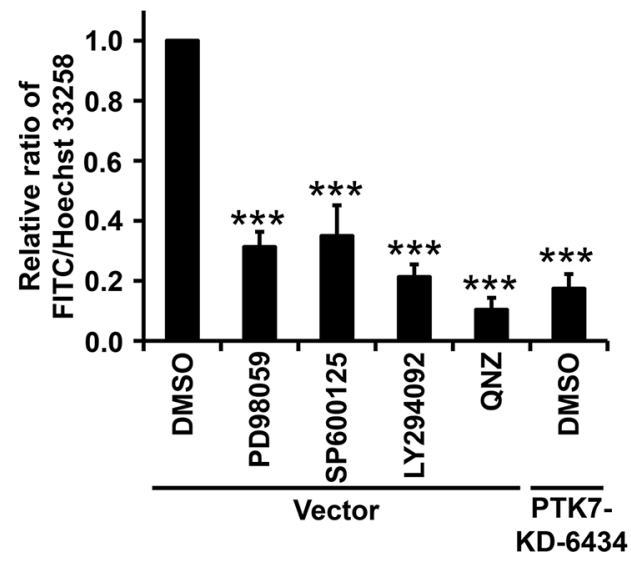

B
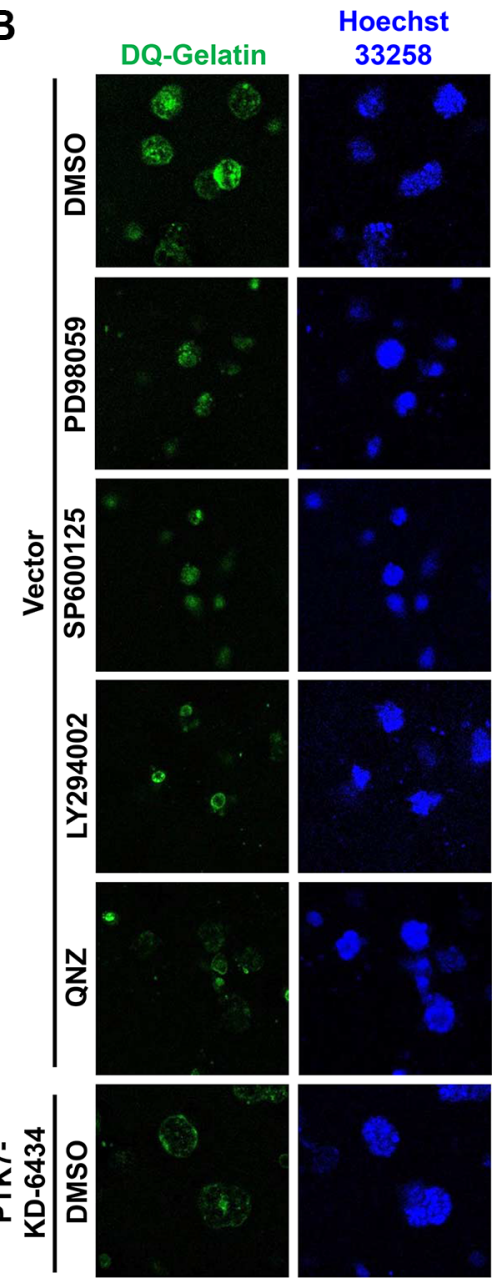

Figure 7: Effect of AP-1 and NF-кB signaling blockade on PTK7-mediated MMP-9 secretion in 2D and 3D TE-10 cell cultures. (A) Subconfluent control vector-transfected and PTK7 knockdown (PTK7-KD-6434) TE-10 cells were incubated in serum-free medium containing PD98059 $(30 \mu \mathrm{M})$, SP600125 $(10 \mu \mathrm{M})$, LY294002 $(10 \mu \mathrm{M})$, QNZ (10 $\mu \mathrm{M}, \mathrm{NF}-\kappa \mathrm{B}$ inhibitor), or DMSO (vehicle) for $24 \mathrm{~h}$. Levels of secreted MMP-9 and MMP-2 in the medium were analyzed by gelatin zymography and western blotting. Levels of PTK7 and GAPDH (loading control) in cell lysates were analyzed by western blotting. HT-1080 conditioned medium served to show positions of MMP-9 and MMP-2. (B and C) Control vector and PTK7 knockdown cells were cultured for $24 \mathrm{~h}$ within a 3D Matrigel matrix containing quenched fluorogenic DQ Gelatin in the presence of PD98059 $(30 \mu \mathrm{M})$, SP600125 (10 $\mu \mathrm{M})$, LY294002 $(10 \mu \mathrm{M})$, QNZ $(10 \mu \mathrm{M})$, or DMSO (vehicle). Nuclei were counterstained with Hoechst 33258, and cells were analyzed by confocal fluorescence microscopy $(\times 200)(B)$ and gelatinolytic activity in the cultures was determined and expressed as the ratio of fluorescein (resulting from DQ-gelatin cleavage)/Hoechst 33258 fluorescence intensity (C). $* * * P<0.001$ vs. DMSO-treated control vector-transfected cells. 
in Supplementary Table S1. Expression vector encoding HA-tagged K179M kinase-deficient AKT (pCMV6-HAAkt-KD [K179M]) was a kind gift of Professor K.-Y. Choi (Yonsei University, Korea). Constructs pLKO.1-shRNAPTK7-6433 and -6434 for human PTK7 knockdown vectors and pLKO.1-control (Sigma-Aldrich) were described previously [8]. Constructs LentiCRISPRv2sgRNA-PTK7-F369 and -F849 for human PTK7 knockout vectors were generated by cloning of oligonucleotide sequences listed in Supplementary Table S2 into LentiCRISPRv2 vector (Addgene, Cambridge, MA, USA).

\section{Generation of PTK7 knockdown and PTK7 knockout ESCC cells}

Production of PTK7 knockdown and PTK7 knockout lentiviruses and infection into ESCC cells were performed as described previously [8]. Puromycinresistant cells were enriched by incubation of the cultures with $2.5 \mu \mathrm{g} / \mathrm{ml}$ puromycin for $14 \mathrm{~d}$. A mixed culture of PTK7 knockdown cells and individual clones of PTK7 knockout cells were maintained in the presence of $1 \mu \mathrm{g} / \mathrm{ml}$ puromycin.

\section{Transfection}

Transfection of expression vectors into cells was carried out using Lipofectamine 2000 (Thermo Fisher Scientific) according to the manufacturer's instructions. Briefly, the media of subconfluent cells in 6-cm dish were replaced with $4 \mathrm{ml}$ of Opti-MEM (Gibco/Thermo Fisher Scientific). A mixture of $4 \mu \mathrm{g}$ of expression vector and $8 \mu \mathrm{l}$ of Lipofectamine 2000 in $0.4 \mathrm{ml}$ Opti-MEM was incubated for $30 \mathrm{~min}$ at room temperature and was added to the cells. After 6-h incubation, the media were changed to $10 \% \mathrm{FBS}$ DMEM and the cells were analyzed for reporter assay at $24 \mathrm{~h}$ and for transient expression at $48 \mathrm{~h}$ after transfection.

\section{Fluorescent gelatin degradation assay}

Cross-linked FITC-gelatin-coated coverslips were prepared as described previously [44]. Briefly, acidwashed glass coverslips were coated with $20 \mu \mathrm{g} / \mathrm{ml}$ FITCgelatin for $2 \mathrm{~h}$ at $37^{\circ} \mathrm{C}$. The coverslips were washed with phosphate-buffered saline (PBS), cross-linked with $0.5 \%$ glutaraldehyde for $15 \mathrm{~min}$, and then quenched with $5 \mathrm{mg} /$ $\mathrm{ml}$ sodium borohydride for $3 \mathrm{~min}$ at $25^{\circ} \mathrm{C}$. The FITC-

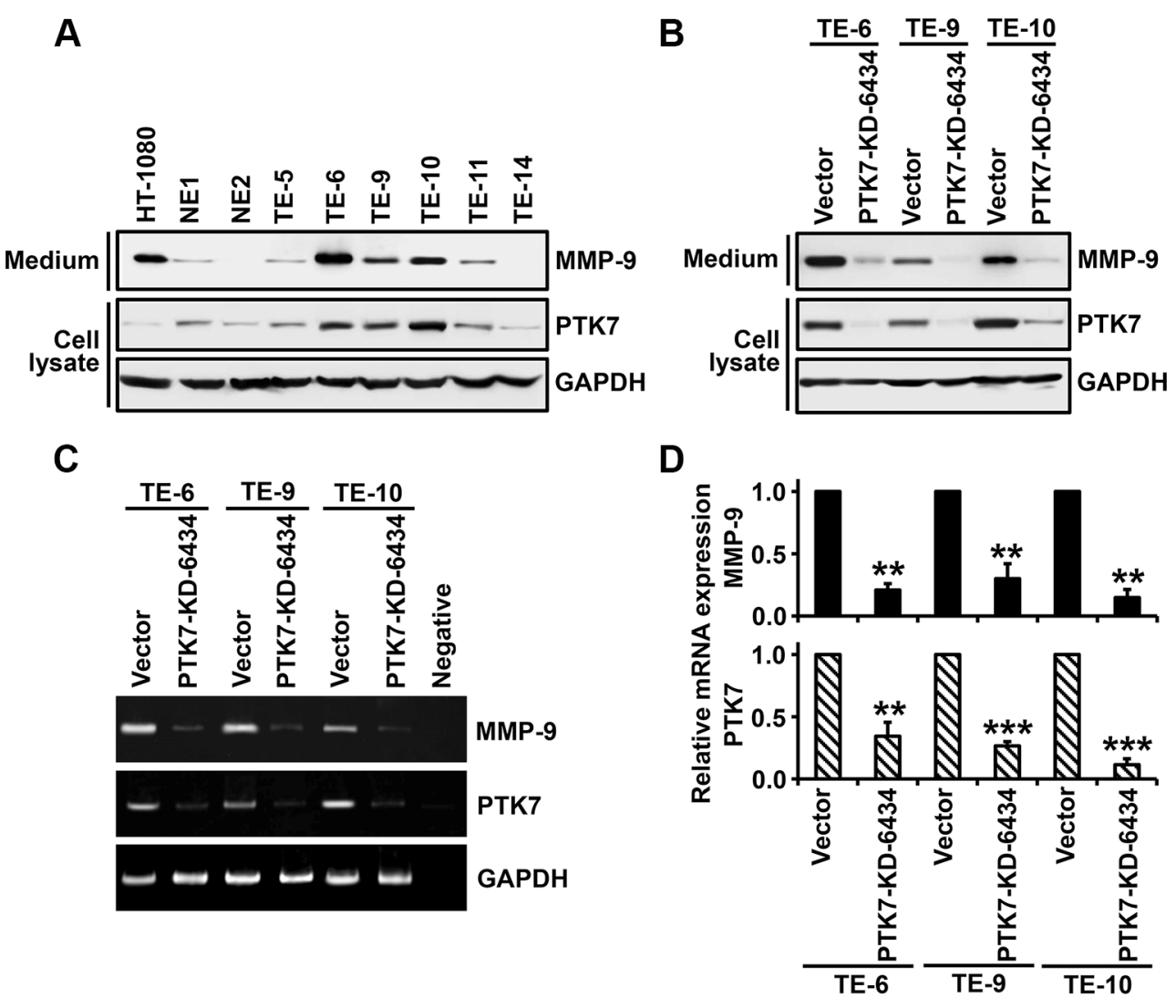

Figure 8: Analysis of PTK7-dependent MMP-9 expression in esophageal epithelial and ESCC cell lines. In non-neoplastic esophageal epithelial cell lines (NE1 and NE2) and ESCC cell lines (TE-5, 6, 9, 10, 11, and 14) (A) and control vector-transfected and PTK7 knockdown (PTK7-KD-6434) TE-6, -9, and -10 cells (B), levels of secreted MMP-9 levels in the medium and levels of PTK7 and GAPDH in cell lysates were analyzed by western blotting. HT-1080 cell lysates served as an MMP-9-positive control. MMP9 and PTK7 mRNA levels were analyzed by conventional $(\mathbf{C})$ and real-time (D) RT-PCR in control and PTK7 knockdown TE-6, -9 , and -10 cells. $* * P<0.01$, $* * * P<0.001 v s$. level in control vector cells. 

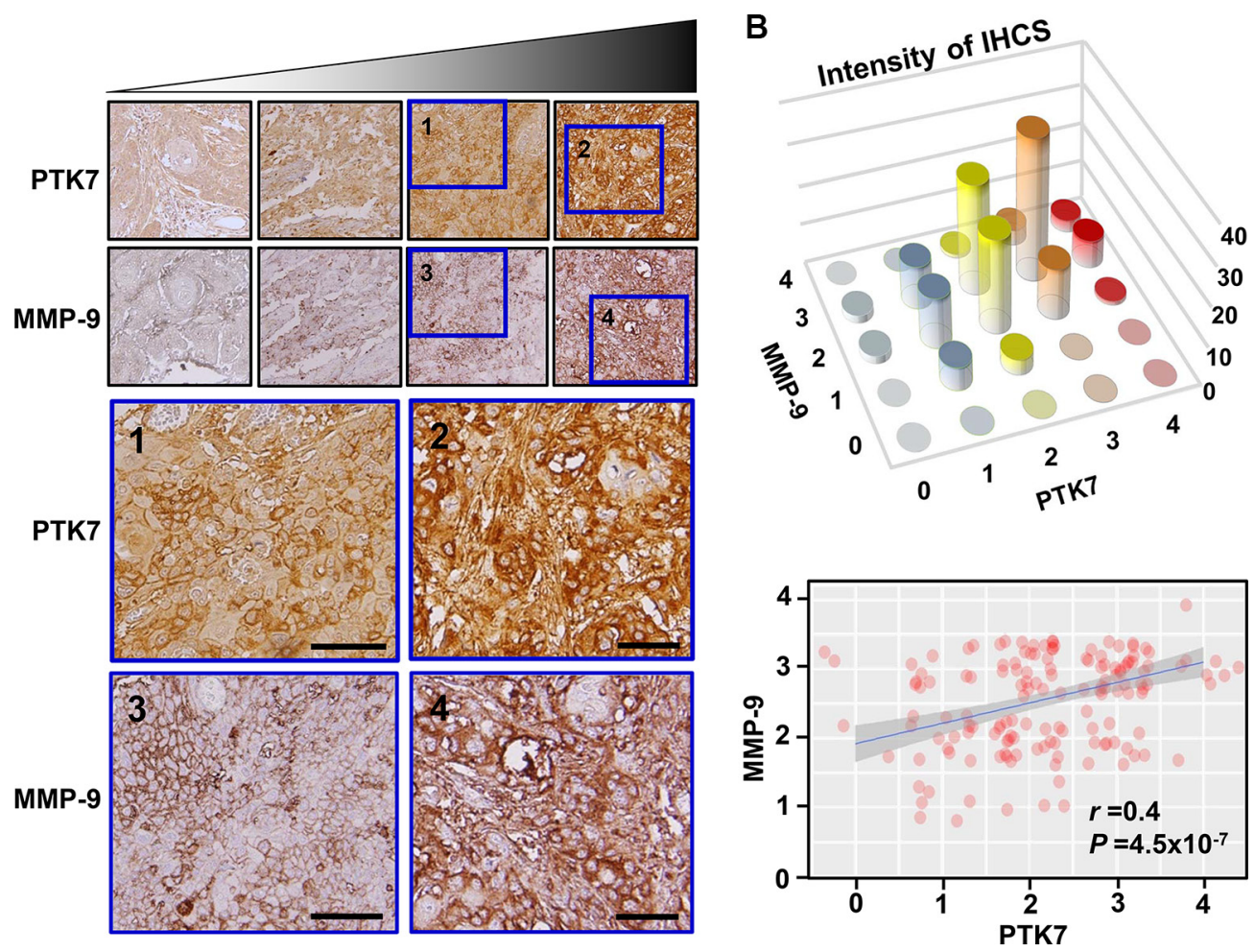

Figure 9: Relationship between PTK7 and MMP-9 expression based on immunohistochemical analysis of ESCC tissue. (A) Representative images of immunohistochemical staining of PTK7 and MMP-9 in serial sections of each ESCC tissue block $(\times 200)$. Areas inside blue boxes were shown at a higher resolution. Scale bar indicates $50 \mu \mathrm{m}$. (B) Distribution (top) and linear relationship determined by Spearman's rank correlation test (bottom) of PTK7 and MMP-9 staining intensity in 155 ESCC tissue samples. $r$ and $P$ values of Spearman's rank correlation are shown.

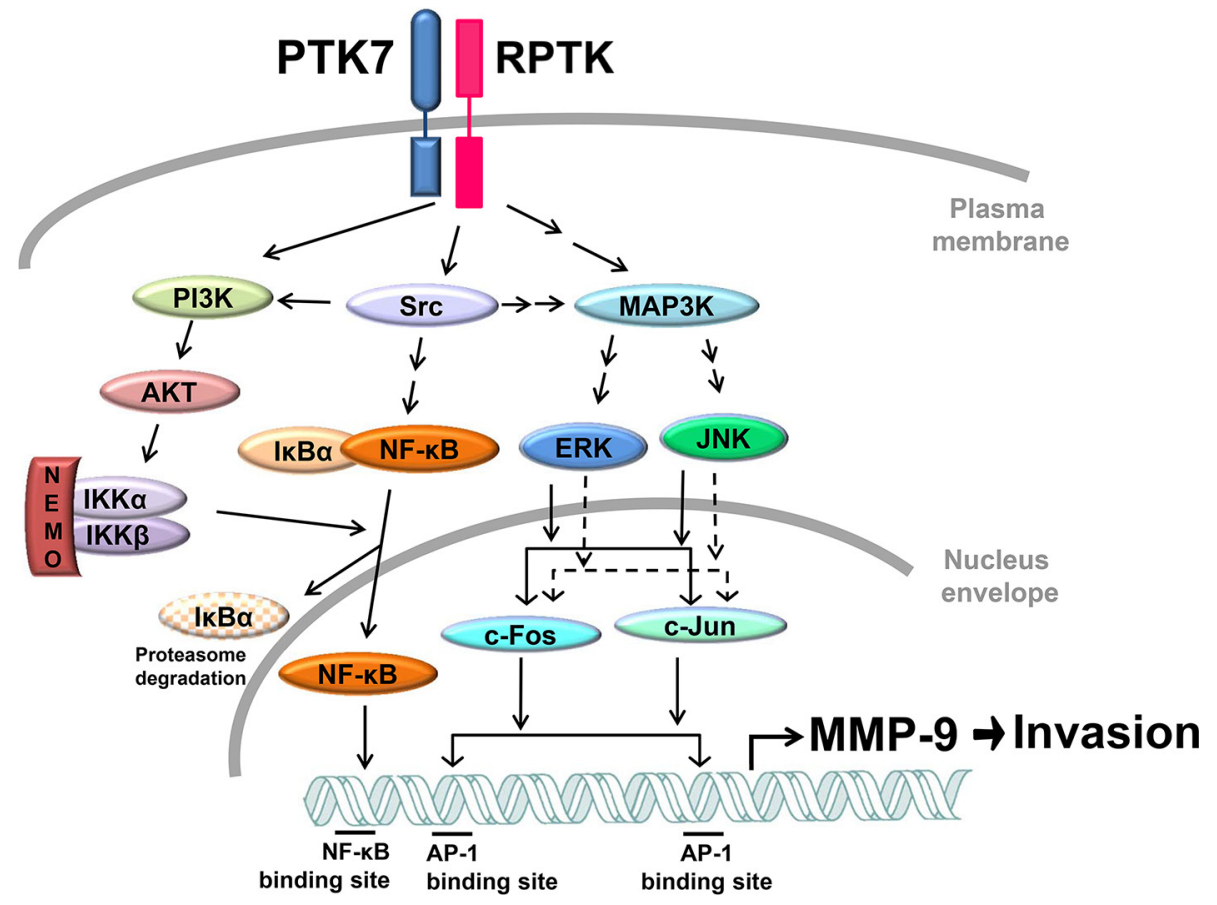

Figure 10: Proposed model for PTK7-mediated MMP-9 induction and invasiveness in TE-10 cells. PTK7 activates the PI3K/AKT and Ras/MAPK pathways via activation of unidentified RPTK and Src. The PI3K-Akt-IKK signal cascade activates NF- $\kappa$ F. ERK and JNK activate AP-1 complex components c-Fos and c-Jun. NF- $\kappa$ B and AP-1 transactivate MMP9 and enhance invasive phenotype of ESCC cells. Solid and dashed arrows indicate activation at the protein and transcriptional levels, respectively. 
gelatin-coated coverslips were washed with PBS again and incubated with 5\% FBS in DMEM for $1 \mathrm{~h}$ at $37^{\circ} \mathrm{C}$. Cells $\left(4 \times 10^{4} /\right.$ well of 24 -well plate $)$ were seeded on the coverslips and incubated for $48 \mathrm{~h}$ at $37^{\circ} \mathrm{C}$ to allow gelatin degradation. The cells were fixed with $3.7 \%$ paraformaldehyde and treated with $1 \%$ Triton X-100. Actin filaments were stained with rhodamine-phalloidin $(500 \mathrm{ng} / \mathrm{ml})$. Nuclei were counterstained with DAPI $(250 \mathrm{ng} / \mathrm{ml})$. Immunofluorescence staining was observed with an Axio fluorescence microscope (Zeiss, Jena, Germany). FITC-gelatin degraded area was measured by ImageJ software (National Institutes of Health, Bethesda, MD, USA) and normalized to DAPI intensity for quantitation of gelatin degradation.

\section{Preparation of conditioned medium and gelatin zymography}

Subconfluent cells were incubated in serumfree medium for $24 \mathrm{~h}$. The conditioned medium was collected by centrifugation at $2000 \mathrm{~g}$ for $5 \mathrm{~min}$ and secreted proteins in the supernatant were precipitated with cold trichloroacetic acid (TCA; Sigma-Aldrich). The precipitated proteins were analyzed using gelatin zymography as described previously [45].

\section{RNA isolation and reverse transcription (RT)- PCR analysis}

Total RNA was isolated from each cell line using TRIzol reagent (Invitrogen). First-strand cDNA was synthesized from total RNA using oligo (dT) ${ }_{15}$ primers and the AMV RT system (Promega, Madison, WI, USA) according to the manufacturer's instructions. PCR was carried out under conditions of 27 cycles of denaturation at $94^{\circ} \mathrm{C}$ for $30 \mathrm{~s}$, annealing (see Supplementary Table S3 for annealing temperatures) for $60 \mathrm{~s}$, and extension at $72^{\circ} \mathrm{C}$ for $30 \mathrm{~s}$. PCR products were analyzed by polyacrylamide gel electrophoresis (PAGE) through 5\% gels. Real-time PCR was performed using the QuantiTect SYBR Green PCR Kit (Qiagen, Hilden, Germany) and the CFX RealTime system (Bio-Rad, Hercules, CA, USA.).

\section{Dual-luciferase reporter assay}

Cells $\left(8 \times 10^{3} /\right.$ well $)$ were seeded in 96 -well plates $16 \mathrm{~h}$ prior to transfection. Luciferase reporter construct pGL3-M9P-wt containing the human wild-type $M M P 9$ promoter or the promoterless vector pGL3-basic was cotransfected with reporter vector pRL-TK encoding Renilla luciferase using Lipofectamine 2000 [46]. After $24 \mathrm{~h}$, luciferase activity was measured using a dualluciferase reporter assay system (Promega) and normalized to Renilla luciferase activity.

\section{Fractionation of cytosolic and nuclear proteins}

Subconfluent cells were separated into cytoplasmic and nuclear fractions as described previously [24], and proteins were analyzed by western blotting.

\section{Preparation of cell lysates, immunoprecipitation, and western blotting}

Subconfluent cells were lysed with RIPA lysis buffer $(50 \mathrm{mM}$ Tris- $\mathrm{HCl}, \mathrm{pH} 7.4,150 \mathrm{mM} \mathrm{NaCl}$, $1 \%$ NP-40, $0.5 \%$ sodium deoxycholate, and $0.1 \%$ SDS) containing $1 \mathrm{mM} \mathrm{NaF}, 1 \mathrm{mM} \mathrm{Na} \mathrm{VO}_{4}$, and Sigmafast protease inhibitor tablets $(2 \mathrm{mM}$ AEBSF, $300 \mathrm{nM}$ aprotinin, $130 \mu \mathrm{M}$ bestatin, $1 \mathrm{mM}$ EDTA, $14 \mu \mathrm{M}$ E-64, and $1 \mu \mathrm{M}$ leupeptin; Sigma-Aldrich). Immunoprecipitation and western blotting were performed as described previously [17].

\section{Gelatinolytic activity in 3D culture}

3D cell culture in Matrigel (Phenol Red-Free; Corning Inc., Corning, NY, USA) containing fluorogenic DQ Gelatin was performed as previously described $[47,48]$. Briefly, cells $\left(5 \times 10^{4} / 100 \mu \mathrm{l}\right)$ were incubated in phenol red-free DMEM containing signaling inhibitors for $30 \mathrm{~min}$, mixed with $100 \mu \mathrm{l}$ of $6 \mathrm{mg} / \mathrm{ml}$ Matrigel containing $50 \mu \mathrm{g} / \mathrm{ml}$ DQ Gelatin and signaling inhibitors, and seeded in 13-mm glass-bottomed dishes (SPL Life Sciences, Pocheon-si, Gyeonggi-do, Korea) coated with $50 \mu \mathrm{l}$ Matrigel. After polymerization of Matrigel, $2 \mathrm{ml}$ culture medium containing signaling inhibitors were added, and the dishes were incubated at $37^{\circ} \mathrm{C}$ for $72 \mathrm{~h}$. Cells were incubated with Hoechst $33258(2 \mu \mathrm{g} / \mathrm{ml})$ for 30 min to counterstain nuclei. Intensity of fluorescence generated by DQ Gelatin cleavage was determined and normalized to that of Hoechst 33258 staining using a confocal microscope (LSM700; Zeiss) and ImageJ software.

\section{Immunohistochemical (IHC) staining of ESCC tissue and statistical analysis}

Preparation and IHC staining of ESCC tissue were performed as described previously [8]. Micrographs were taken of stained tissue and evaluated for staining intensity by a pathologist blinded to the identity of the samples. Intensity of PTK7 or MMP-9 staining was scored on a scale of 0 (low) to 4 (high).

Statistical analysis of association of PTK7 and MMP-9 expression was carried out using Spearman's rank correlation. Correlation and statistical comparisons were performed using the R package 'pspearman' (version $0.3-0)$. 


\section{Statistical analysis}

All data subjected to statistical analysis were obtained from at least three independent experiments and are expressed as mean \pm standard deviation. Statistical significance was analyzed by Student's $t$-test unless specified otherwise. A $p$-value $<0.05$ was considered significant.

\section{CONFLICTS OF INTEREST}

The authors declare no conflicts of interest.

\section{GRANT SUPPORT}

This work was supported by grants from the National Research Foundation of Korea (No. 2013R1A2A2A01013884 and No. 2014M3C9A2064597).

\section{REFERENCES}

1. Lee ST, Strunk KM, Spritz RA. A survey of protein tyrosine kinase mRNAs expressed in normal human melanocytes. Oncogene. 1993; 8:3403-3410.

2. Park SK, Lee HS, Lee ST. Characterization of the human full-length PTK7 cDNA encoding a receptor protein tyrosine kinase-like molecule closely related to chick KLG. J Biochem. 1996; 119:235-239.

3. Banga SS, Ozer HL, Park SK, Lee ST. Assignment of PTK7 encoding a receptor protein tyrosine kinase-like molecule to human chromosome $6 \mathrm{p} 21.1 \longrightarrow \mathrm{p} 12.2$ by fluorescence in situ hybridization. Cytogenet Cell Genet. 1997; 76:43-44.

4. Murphy JM, Zhang Q, Young SN, Reese ML, Bailey FP, Eyers PA, Ungureanu D, Hammaren H, Silvennoinen O, Varghese LN, Chen K, Tripaydonis A, Jura N, et al. A robust methodology to subclassify pseudokinases based on their nucleotide-binding properties. Biochem J. 2014; 457:323-334.

5. Lu X, Borchers AG, Jolicoeur C, Rayburn H, Baker JC, Tessier-Lavigne M. PTK7/CCK-4 is a novel regulator of planar cell polarity in vertebrates. Nature. 2004; 430:93-98.

6. Puppo F, Thome V, Lhoumeau AC, Cibois M, Gangar A, Lembo F, Belotti E, Marchetto S, Lecine P, Prebet T, Sebbagh M, Shin WS, Lee ST, et al. Protein tyrosine kinase 7 has a conserved role in Wnt/beta-catenin canonical signalling. EMBO Rep. 2011; 12:43-49.

7. Martinez S, Scerbo $P$, Giordano $M$, Daulat AM, Lhoumeau AC, Thome V, Kodjabachian L, Borg JP. The PTK7 and ROR2 Protein Receptors Interact in the Vertebrate WNT/Planar Cell Polarity (PCP) Pathway. J Biol Chem. 2015; 290:30562-30572.

8. Shin WS, Kwon J, Lee HW, Kang MC, Na HW, Lee ST, Park JH. Oncogenic role of protein tyrosine kinase 7 in esophageal squamous cell carcinoma. Cancer Sci. 2013; 104:1120-1126.
9. Mossie K, Jallal B, Alves F, Sures I, Plowman GD, Ullrich A. Colon carcinoma kinase-4 defines a new subclass of the receptor tyrosine kinase family. Oncogene. 1995; 11:2179-2184.

10. Saha S, Bardelli A, Buckhaults P, Velculescu VE, Rago C, St Croix B, Romans KE, Choti MA, Lengauer C, Kinzler KW, Vogelstein B. A phosphatase associated with metastasis of colorectal cancer. Science. 2001; 294:1343-1346.

11. Prebet T, Lhoumeau AC, Arnoulet C, Aulas A, Marchetto S, Audebert S, Puppo F, Chabannon C, Sainty D, Santoni MJ, Sebbagh M, Summerour V, Huon Y, et al. The cell polarity PTK7 receptor acts as a modulator of the chemotherapeutic response in acute myeloid leukemia and impairs clinical outcome. Blood. 2010; 116:2315-2323.

12. Muller-Tidow C, Schwable J, Steffen B, Tidow N, Brandt B, Becker K, Schulze-Bahr E, Halfter H, Vogt U, Metzger R, Schneider PM, Buchner T, Brandts C, et al. High-throughput analysis of genome-wide receptor tyrosine kinase expression in human cancers identifies potential novel drug targets. Clin Cancer Res. 2004; 10:1241-1249.

13. Gobble RM, Qin LX, Brill ER, Angeles CV, Ugras S, O'Connor RB, Moraco NH, Decarolis PL, Antonescu C, Singer S. Expression profiling of liposarcoma yields a multigene predictor of patient outcome and identifies genes that contribute to liposarcomagenesis. Cancer Res. 2011; 71:2697-2705.

14. Gorringe KL, Boussioutas A, The Melbourne Gastric Cancer Group, Peter Mac Microarray Facility Bowtell DD. Novel regions of chromosomal amplification at $6 \mathrm{p} 21,5 \mathrm{p} 13$, and $12 \mathrm{q} 14$ in gastric cancer identified by array comparative genomic hybridization. Genes Chromosomes Cancer. 2005; 42:247-259.

15. Jin J, Ryu HS, Lee KB, Jang JJ. High expression of protein tyrosine kinase 7 significantly associates with invasiveness and poor prognosis in intrahepatic cholangiocarcinoma. PLoS One. 2014; 9:e90247.

16. Meng L, Sefah K, O’Donoghue MB, Zhu G, Shangguan D, Noorali A, Chen Y, Zhou L, Tan W. Silencing of PTK7 in colon cancer cells: caspase-10-dependent apoptosis via mitochondrial pathway. PLoS One. 2010; 5:e14018.

17. Shin WS, Na HW, Lee ST. Biphasic effect of PTK7 on KDR activity in endothelial cells and angiogenesis. Biochim Biophys Acta. 2015; 1853:2251-2260.

18. Asad M, Wong MK, Tan TZ, Choolani M, Low J, Mori S, Virshup D, Thiery JP, Huang RY. FZD7 drives in vitro aggressiveness in Stem-A subtype of ovarian cancer via regulation of non-canonical Wnt/PCP pathway. Cell Death Dis. 2014; 5:e1346.

19. Kim JH, Kwon J, Lee HW, Kang MC, Yoon HJ, Lee ST, Park JH. Protein tyrosine kinase 7 plays a tumor suppressor role by inhibiting ERK and AKT phosphorylation in lung cancer. Oncol Rep. 2014; 31:2708-2712.

20. Easty DJ, Mitchell PJ, Patel K, Florenes VA, Spritz RA, Bennett DC. Loss of expression of receptor tyrosine kinase family genes PTK7 and SEK in metastatic melanoma. Int J Cancer. 1997; 71:1061-1065. 
21. Behbahani TE, Thierse C, Baumann C, Holl D, Bastian PJ, von Ruecker A, Muller SC, Ellinger J, Hauser S. Tyrosine kinase expression profile in clear cell renal cell carcinoma. World J Urol. 2012; 30:559-565.

22. Wang H, Li G, Yin Y, Wang J, Wang H, Wei W, Guo Q, Ma H, Shi Q, Zhou X, Wang J. PTK7 protein is decreased in epithelial ovarian carcinomas with poor prognosis. Int $\mathrm{J}$ Clin Exp Pathol. 2014; 7:7881-7889.

23. Olson MW, Gervasi DC, Mobashery S, Fridman R. Kinetic analysis of the binding of human matrix metalloproteinase-2 and -9 to tissue inhibitor of metalloproteinase (TIMP)-1 and TIMP-2. J Biol Chem. 1997; 272:29975-29983.

24. Na HW, Shin WS, Ludwig A, Lee ST. The cytosolic domain of PTK7, generated from sequential cleavage by ADAM17 and gamma-secretase, enhances cell proliferation and migration in colon cancer cells. J Biol Chem. 2012; 287:25001-25009.

25. Yabluchanskiy A, Ma Y, Iyer RP, Hall ME, Lindsey ML. Matrix metalloproteinase-9: Many shades of function in cardiovascular disease. Physiology (Bethesda). 2013; 28:391-403.

26. Agarwal A, Das K, Lerner N, Sathe S, Cicek M, Casey G, Sizemore N. The AKT/I kappa B kinase pathway promotes angiogenic/metastatic gene expression in colorectal cancer by activating nuclear factor-kappa $\mathrm{B}$ and beta-catenin. Oncogene. 2005; 24:1021-1031.

27. St-Pierre Y, Couillard J, Van Themsche C. Regulation of MMP-9 gene expression for the development of novel molecular targets against cancer and inflammatory diseases. Expert Opin Ther Targets. 2004; 8:473-489.

28. Mujoo K, Choi BK, Huang Z, Zhang N, An Z. Regulation of ERBB3/HER3 signaling in cancer. Oncotarget. 2014; 5:10222-10236. doi: 10.18632/oncotarget.2655.

29. Goldberg GS, Alexander DB, Pellicena P, Zhang ZY, Tsuda H, Miller WT. Src phosphorylates Cas on tyrosine 253 to promote migration of transformed cells. J Biol Chem. 2003; 278:46533-46540.

30. Andreeva A, Lee J, Lohia M, Wu X, Macara IG, Lu X. PTK7-Src signaling at epithelial cell contacts mediates spatial organization of actomyosin and planar cell polarity. Dev Cell. 2014; 29:20-33.

31. Ishizawar R, Parsons SJ. c-Src and cooperating partners in human cancer. Cancer Cell. 2004; 6:209-214.

32. Chen JC, Yang ST, Lin CY, Hsu CJ, Tsai CH, Su JL, Tang CH. BMP-7 enhances cell migration and alphavbeta3 integrin expression via a c-Src-dependent pathway in human chondrosarcoma cells. PLoS One. 2014; 9:e112636.

33. Perkins ND. Post-translational modifications regulating the activity and function of the nuclear factor kappa B pathway. Oncogene. 2006; 25:6717-6730.

34. Wolf K, Friedl P. Extracellular matrix determinants of proteolytic and non-proteolytic cell migration. Trends Cell Biol. 2011; 21:736-744.
35. Li Y, Ma J, Guo Q, Duan F, Tang F, Zheng P, Zhao Z, Lu G. Overexpression of MMP-2 and MMP-9 in esophageal squamous cell carcinoma. Dis Esophagus. 2009; 22:664-667.

36. Sakamoto K, Maeda S, Hikiba Y, Nakagawa $H$, Hayakawa Y, Shibata W, Yanai A, Ogura K, Omata M. Constitutive NF-kappaB activation in colorectal carcinoma plays a key role in angiogenesis, promoting tumor growth. Clin Cancer Res. 2009; 15:2248-2258.

37. Fukuyama R, Ng KP, Cicek M, Kelleher C, Niculaita R, Casey G, Sizemore N. Role of IKK and oscillatory NFkappaB kinetics in MMP-9 gene expression and chemoresistance to 5-fluorouracil in RKO colorectal cancer cells. Mol Carcinog. 2007; 46:402-413.

38. Endo F, Nishizuka SS, Kume K, Ishida K, Katagiri H, Ishida K, Sato K, Iwaya T, Koeda K, Wakabayashi G. A compensatory role of NF-kappaB to p53 in response to 5-FU-based chemotherapy for gastric cancer cell lines. PLoS One. 2014; 9:e90155.

39. Shin WS, Maeng YS, Jung JW, Min JK, Kwon YG, Lee ST. Soluble PTK7 inhibits tube formation, migration, and invasion of endothelial cells and angiogenesis. Biochem Biophys Res Commun. 2008; 371:793-798.

40. Deng W, Tsao SW, Guan XY, Lucas JN, Si HX, Leung CS, Mak P, Wang LD, Cheung AL. Distinct profiles of critically short telomeres are a key determinant of different chromosome aberrations in immortalized human cells: whole-genome evidence from multiple cell lines. Oncogene. 2004; 23:9090-9101.

41. Cheung PY, Deng W, Man C, Tse WW, Srivastava G, Law S, Tsao SW, Cheung AL. Genetic alterations in a telomerase-immortalized human esophageal epithelial cell line: implications for carcinogenesis. Cancer Lett. 2010; 293:41-51.

42. Kim H, Saldova R, Park JH, Lee YH, Harvey DJ, Wormald MR, Wynne K, Elia G, Kim HJ, Rudd PM, Lee ST. The presence of outer arm fucose residues on the N-glycans of tissue inhibitor of metalloproteinases-1 reduces its activity. J Proteome Res. 2013; 12:3547-3560.

43. Jo Y, Yeon J, Kim HJ, Lee ST. Analysis of tissue inhibitor of metalloproteinases-2 effect on pro-matrix metalloproteinase- 2 activation by membrane-type 1 matrix metalloproteinase using baculovirus/insect-cell expression system. Biochem J. 2000; 345 Pt 3:511-519.

44. Bowden ET, Coopman PJ, Mueller SC. Invadopodia: unique methods for measurement of extracellular matrix degradation in vitro. Methods Cell Biol. 2001; 63:613-627.

45. Choi YJ, Lee YH, Lee ST. Galangin and kaempferol suppress phorbol-12-myristate-13-acetate-induced matrix metalloproteinase-9 expression in human fibrosarcoma HT1080 cells. Mol Cells. 2015; 38:151-155.

46. Hah N, Lee ST. An absolute role of the PKC-dependent NFkappaB activation for induction of MMP-9 in hepatocellular 
carcinoma cells. Biochem Biophys Res Commun. 2003; 305:428-433.

47. Gillet L, Roger S, Besson P, Lecaille F, Gore J, Bougnoux P, Lalmanach G, Le Guennec JY. Voltage-gated Sodium Channel Activity Promotes Cysteine Cathepsin-dependent Invasiveness and Colony Growth of Human Cancer Cells. J Biol Chem. 2009; 284:8680-8691.
48. Koh M, Woo Y, Valiathan RR, Jung HY, Park SY, Kim YN, Kim HR, Fridman R, Moon A. Discoidin domain receptor 1 is a novel transcriptional target of ZEB1 in breast epithelial cells undergoing H-Ras-induced epithelial to mesenchymal transition. Int J Cancer. 2015; 136:E508-520. 